\title{
Kukasz Niewiński
}

Wydział Historyczno-Socjologiczny

Uniwersytet w Białymstoku

\section{4. pułk piechoty $z$ Luizjany w wojnie secesyjnej w latach 1861-1865}

Temat 14. pułku piechoty z Luizjany ${ }^{1}$, noszącego też nazwę „polskiego pułku" (Polish Regiment), nie został dotąd należycie opracowany i to zarówno w historiografii amerykańskiej, jak i polskiej. Autorzy z USA poświęcili mu niewiele uwagi ${ }^{2}$. Z kolei Amerykanie polskiego pochodzenia piszący o wojnie secesyjnej, skupiali się na dwóch rodakach, organizatorach tej jednostki - Kacprze Tochmanie i Walerym Sulakowskim³ ${ }^{3}$ Badania na ww. temat rozpoczął w 2007 r. autor prezentowanego tekstu ${ }^{4}$. Obecnie znalazł on w tym zakresie naśladowców 5 .

1 Początkowo jednostka ta funkcjonowała jako 13. pułk piechoty z Luizjany i pod tym numerem została włączona do armii Południa 24 sierpnia 1861 r. Ostatecznie 21 września $1861 \mathrm{r}$. nadano jej nr 14. Taki stan rzeczy utrzymał się do końca wojny - Journal of the Congress of the Confederate States of America, Washington D.C. 1904, t. I, s. 437, 501.

2 E. Lonn, Foreigners in the Confederacy, wyd. 3, Chapell Hill, NC 2002 (wyd. 1 - 1940); J. D. Winters, The Civil War in Louisiana, wyd. 2, Baton Rouge, LA 1979; T. L. Jones, Lee's Tigers: The Louisiana Infantry in the Army of Northern Virginia, Baton Rouge, LA 1987; A. W. Bergeron, Jr, Guide to Louisiana. Confederate Military Units 1861-1865, Baton Rouge, LA 1995, s. 106-109; Aktualnie ten stan zaczyna się nieco zmieniać. Pojawiają się nowe opracowania, do których należy zaliczyć chociażby prace takie jak: Soldiering for Glory. The Civil War Letters of Colonel Frank Schaller, Twenty Second Mississippi Infantry, ed. by M. W. Schaller, M. N. Schalller, Columbia, SC 2007; J. T. Glatthaar, General Lee's Army. From Victory to Collapse, New York 2009, s. 27-28.

3 M. Haiman, Historia udziału Polaków w amerykańskiej wojnie domowej, Chicago, IL. 1928; W. S. Kuniczak, My name is million: an illustrated history of the Poles in America, wyd. 1, Garden City, NY 1978; J. A. Wytrwal, Poles in American History and Tradition, Detroit, MI 1969; F. C. Kajencki, The Louisiana Tiger: Sulakowski, „Polish American Studies” (dalej: PAS) 1966 (Lipiec-Grudzień), t. 23, nr 2, s. 82-88; Idem, The Louisiana Tiger, „Louisiana History” 1974 (Zima), t. XV, nr 1, s. 49-58; S. H. Uminski, Poles and the Confederacy, „PAS” 1965 (Lipiec-Grudzień), t. 23, nr 2, s. 99-106; Idem, Two Polish Confederates, „PAS” 1966 (Lipiec-Grudzień), t. 23 , nr 2, s. 65-81.

4 Ł. Niewiński, Brygada Polska $w$ armii Konfederacji $w$ latach 1861-1865, „Studia i Materiały do Historii Wojskowości”, t. XLIII, Białystok 2007, s. 223-250.

5 Np. P. Derengowski, 1 i 2 pułk piechoty Brygady Polskiej w wojskach Konfederacji 1861-1865 (14 i 15 pułk piechoty z Luizjany), „Przegląd Historyczno-Wojskowy” Warszawa 2011, t. 12 (63), nr 2 (235), s. 25-74. 
Przez wiele lat w polskiej historiografii panował, nieprawdziwy, jak się okazało, pogląd o licznej polskiej reprezentacji w składzie 14. pułku piechoty z Luizjany. Pułk ten, wchodzący w skład armii Skonfederowanych Stanów Ameryki, przez cały okres wojny secesyjnej brał udział w walkach na froncie wschodnim, głównie w Wirginii. Bogdan Grzeloński w jednej ze swoich prac jako pierwszy w Polsce obwieścił, że w skład dwu-pułkowej Brygady Polskiej (składającej się z 14. i 15. pułku piechoty) wchodziło 1485 obcokrajowców i 285 Polaków $^{6}$. Za nim rozpowszechnili ten pogląd kolejni autorzy ${ }^{7}$. Dopiero niedawno, po przeprowadzeniu gruntownych badań rejestru jednostki, okazało się, że Polaków było najwyżej 22, a w rzeczywistości nie więcej niż $10 \mathrm{w} 14$. pułku i najwyżej $2 \mathrm{w}$ 15. pułku. $\mathrm{Z}$ kolei w niniejszym artykule udowadniam, że tylko w 14. pułku znajdowało się więcej Amerykanów, niż podawała E. Lonn dla całej brygady - 290 i to przy założeniu, że znane jest miejsce urodzenia niespełna połowy jego żołnierzy. Nie sprawdzałem takowych danych dla 15. pułku z Luizjany.

Niniejszy tekst nie ma jednak na celu ustalenia liczby Polaków w regimencie (choć niewielka wzmianka na ten temat pojawi się w jego dalszej części), ani opisu szlaku bojowego regimentu, gdyż zostało to już opisane w literaturze ${ }^{9}$. Celem artykułu jest przedstawienie wyników danych statystycznych dotyczących tej jednostki. Badaniami objęto: daty i miejsca zaciągu, wiek i inne dane osobowe (imię, nazwisko, wzrost, cera, kolor oczu, kolor włosów, zawód, kraj urodzenia, miejsce zamieszkania), straty powstałe z przyczyn bojowych i niebojowych, rodzaje zwolnień z jednostki, kwestie związane z jeńcami wojennymi, dezercją i sądami polowymi.

Już na wstępie autor stawia też tezę, którą postara się udowodnić w dalszej części tekstu, że 14. regiment z Luizjany - mimo polskiej nazwy - był w rzeczywistości jednostką złożoną głównie z Irlandczyków.

Niniejszy artykuł został oparty głównie na źródłach archiwalnych dostępnych w National Archives and Records Administration w Waszyngtonie oraz pracy Andrew B. Bootha ${ }^{10}$. Tekst stanowi kontynuację badań autora nad udziałem ,polskich” jednostek w amerykańskiej wojnie domowej ${ }^{11}$.

6 B. Grzeloński, I. Rusinowa, Polacy $w$ wojnach amerykańskich 1775-83, 1861-65, Warszawa 1973, s. 182. B. Grzeloński podał tę liczbę za J. A. Wytrwalem, op. cit., s. 194-195. Ten z kolei dane zapożyczył z pracy E. Lonn, op. cit., s. 161. Jednak w przeciwieństwie do B. Grzelońskiego, J. A. Wytrwal dobrze przetłumaczył cytat E. Lonn jako: 1485 obcokrajowców i 285 Amerykanów.

7 M.in. J. Szkudliński, Chancellorsville 1863, Warszawa 2006, s. 19, 121; J. Drohojowski, Polacy w Ameryce, Warszawa 1976, s. 87; W. Fijałkowski, Polacy i ich potomkowie w historii Stanów Zjednoczonych Ameryki, Warszawa 1978, s. 89; A. Ławrowski, Polacy w dziejach Stanów Zjednoczonych, Warszawa 1977, s. 26.

8 Ł. Niewiński, op. cit., s. 223-250. Wzmiankował o tym także P. Derengowski, op. cit., s. 73.

9 Więcej o tym w: Ł. Niewiński, op. cit., s. 239-241; P. Derengowski, op. cit., s. 25-74.

10 NARA, M 320 Compiled Service Records of Confederate Soldiers Who Served in Organizations from the State of Louisiana, roll 0253-0263; Records of Louisiana Confederate Soldiers and Louisiana Confederate Commands, t. I-III, pod red. A. B. Bootha, New Orleans, LA 1920. 


\section{Dane statystyczne dotyczące 14. pułku piechoty z Luizjany}

Przez blisko cztery lata funkcjonowania jednostki (maj 1861 r. - kwiecień 1865 r.) przewinęło się przez nią 1296 żołnierzy ${ }^{12}$. Z tej liczby tylko 27 osób (2\%), w tym 2 oficerów, skapitulowało wraz z Armią Północnej Wirginii generała Roberta E. Lee pod Appomattox Court House w dniach 9-10 kwietnia 1865 r. $^{13}$ W pracy Andrew B. Bootha można znaleźć co prawda aż 1382 żołnierzy, którzy zostali przydzieleni do 14. pułku z Luizjany, jednak część z nich przynależała do kawalerii, część nazwisk się powtarzała, a 8 osób zostało wykreślonych z rejestru ${ }^{14}$. Z kolei A. W. Bergeron Jr. podaje, że 14. pułk liczył 1026 żołnierzy ${ }^{15}$. Dla potrzeb niniejszego artykułu przyjąłem liczbę 1296 żołnierzy, których status mogłem zweryfikować w swoich badaniach.

$\mathrm{Z}$ ogółu żołnierzy pułku (1296) termin zaciągu znany jest u $1124 \mathrm{z}$ nich $(86,7 \%)^{16}$. W wypadku 172 osób $(13,3 \%)$ brakuje takich danych. Faktycznie zaciąg do jednostki rozpoczął się w drugiej połowie maja $1861 \mathrm{r}$. i był prowadzony w Nowym Orleanie oraz w parafii Carroll. Ponadto akcja rekrutacyjna objęła swoim zasięgiem inne miejscowości w stanie Luizjana, np. Amite City czy Vidalia, a nawet miasta: Natchez w stanie Missisipi oraz Lynchburg w stanie Wirginia. Ochotnicy zgłaszali się do jednostki i byli rejestrowani również w obozach pułku na terenie Luizjany (głównie Camp Pulaski, Camp Moore, Camp Martin), czy Wirginii (Camp Lewis, Camp Davis). W pierwszych trzech miesiącach do regimentu zaciągnęło się aż 1080 osób (co stanowiło 96\% wśród tych ze znanym terminem zaciągu i 83,3\% ogólnego stanu osobowego) - odpowiednio w maju - 187, w czerwcu - 633, w lipcu - 260. Szczegółowe dane dotyczące 16 najpopularniejszych dni zaciągu (rejestracja 10 i więcej osób) znajdują się w tabeli 1 .

We wrześniu 1861 r. po stratach związanych z buntem w Grand Junction podjęto starania rekrutacyjne także w stolicy Konfederacji - Richmond ${ }^{17}$. Niestety

11 Ł. Niewiński, op. cit., s. 223-250; Idem, Legion Polski $w$ armii Unii $w$ latach 1861-1865, „Studia i Materiały do Historii Wojskowości”, t. XLVI, Białystok 2009 s. 81-114; Idem, Polacy $z$ 31. putku piechoty nowojorskiej $w$ wojnie secesyjnej $w$ latach 1861-1863, „Białostockie Teki Historyczne", t. 10, Białystok 2012, s. 117-138.

12 Dane statystyczne są dziełem autora. Wszystkie wykonano na podstawie: NARA, M 320 Compiled Service Records..., roll 0253-0263; Records of Louisiana Confederate Soldiers..., t. I-III.

13 The Appomattox Roster. A List of the paroles of the Army of Northern Virginia issued at Appomattox Court House on April 9, 1865, reprint, New York 1962, s. 230-232.

${ }^{14}$ Records of Louisiana Confederate Soldiers..., t. I-III.

15 A. W. Bergeron, Jr, op. cit., s. 109.

16 Dane procentowe przedstawione są w zaokrągleniu do jednego miejsca po przecinku, wyjątkowo do dwóch miejsc po przecinku.

17 14. pułk piechoty z Luizjany stanowił, nawet jak na warunki panujące w armii Konfederacji, 
Tabela 1. Najpopularniejsze dni zaciągu do 14. pułku piechoty z Luizjany ${ }^{18}$

\begin{tabular}{|c|c|c|c|}
\hline $\begin{array}{c}\text { Pełne daty (dzień-miesiąc-rok) } \\
\text { i miejsce zaciągu }\end{array}$ & Liczba żołnierzy & \% z 1124 osób & \% z 1296 osób \\
\hline 25 czerwca 1861 - Nowy Orlean & 135 & $12,0 \%$ & $10,4 \%$ \\
\hline 3 czerwca 1861 - Nowy Orlean & 107 & $9,5 \%$ & $8,3 \%$ \\
\hline 27 lipca 1861 - Nowy Orlean & 99 & $8,8 \%$ & $7,6 \%$ \\
\hline 27 maja 1861 - Nowy Orlean & 94 & $8,4 \%$ & $7,3 \%$ \\
\hline 12 czerwca 1861 - Nowy Orlean & 90 & $8,0 \%$ & $6,9 \%$ \\
\hline 6 czerwca 1861 - Nowy Orlean & 83 & $7,4 \%$ & $6,4 \%$ \\
\hline 20 maja 1861 - Carroll & 80 & $7,1 \%$ & $6,2 \%$ \\
\hline 19 czerwca 1861 - Nowy Orlean & 70 & $6,2 \%$ & $5,4 \%$ \\
\hline 1 lipca 1861 - Nowy Orlean & 63 & $5,6 \%$ & $4,9 \%$ \\
\hline 22 czerwca 1861 - Nowy Orlean & 60 & $5,3 \%$ & $4,6 \%$ \\
\hline 30 czerwca 1861 - Camp Pulaski & 19 & $1,7 \%$ & $1,5 \%$ \\
\hline 4 lipca 1861 - Amite City & 16 & $1,4 \%$ & $1,2 \%$ \\
\hline 27 czerwca 1861 - Nowy Orlean & 14 & $1,2 \%$ & $1,1 \%$ \\
\hline 19 czerwca 1861 - Vidalia & 11 & $1,0 \%$ & $0,8 \%$ \\
\hline 2 lipca 1861 - Nowy Orlean & 10 & $0,9 \%$ & $0,8 \%$ \\
\hline 5 lipca 1861 - Nowy Orlean & 10 & $0,9 \%$ & $0,8 \%$ \\
\hline
\end{tabular}

działania te przyniosły nikłe rezultaty gdyż w szeregi pułku wstąpiło zaledwie 7 rekrutów. W pozostałych miesiącach $1861 \mathrm{r}$. do pułku przyjęto tylko 5 osób. Ze względu na rozwiązanie jednej kompanii po wydarzeniach w Grand Junction oraz wskutek dezercji, na początku 1862 r. wznowiono akcję rekrutacyjną na terenie Luizjany. Biura werbunkowe utworzono najpierw w Waterproof (styczeń - luty), a następnie w Nowym Orleanie (marzec - początek kwietnia). Do tej akcji oddelegowano kilku oficerów i sierżantów. Efekty rekrutacji były niewielkie. W skład regimentu zaciągnięto zaledwie 25 osób - $10 \mathrm{w}$ Waterproof i 15 w Nowym Orleanie. Ponadto część z oddelegowanych oficerów w wyniku rozpoczętej ofensywy wojsk Północy znalazła się za liniami wroga i nie wróciła już do macierzystej jednostki.

niezdyscyplinowaną jednostkę. Uwidoczniło się to szczególnie w trakcie transportu regimentu do Wirginii w sierpniu 1861 r. Ówczesny dowódca pułku - Walery Sulakowski - na czas transportu nakazał wprowadzenie całkowitej prohibicji wśród swoich żołnierzy. Pomimo to części z nich udało się do wagonów przeszmuglować whiskey. Na postoju w Grand Junction w Tennessee podchmieleni żołnierze wszczęli zamieszki i starli się ze swoimi oficerami. W rezultacie straty wyniosły 7 zabitych i 19 rannych - na podst. J. T. Glaathar, op. cit., s. 27-28. Z kolei A. W. Bergeron, Jr. podawał, że straty jednostki wyniosły 5 zabitych - A. W. Bergeron, Jr, op. cit., s. 109. Straty te nie zostały udokumentowane $\mathrm{w}$ oficjalnych dokumentach. Być może tych 8 żołnierzy wykreślonych $\mathrm{z}$ rejestru stanowili zabici $\mathrm{w}$ tym niesławnym wydarzeniu (dop. - Ł.N.)

18 Dane we wszystkich tabelach umieszczonych w tekście są dziełem autora. 
Tabela 2. Miejsce zaciągu żołnierzy z 14. pułku piechoty z Luizjany

\begin{tabular}{|l|c|c|}
\hline \multicolumn{1}{|c|}{ Miejsce zaciągu } & $\begin{array}{c}\text { Liczba } \\
\text { żołnierzy }\end{array}$ & $\begin{array}{c}\% \text { z } 1124 \text { ludzi - \% z 1296 ludzi } \\
\text { (dane \% w przybliżeniu do 0.1\%) }\end{array}$ \\
\hline Nowy Orlean, Luizjana (dalej La) & 916 & $81,5 \%-70,7 \%$ \\
parafia Carroll, La & 80 & $7,1 \%-6,2 \%$ \\
Camp Pulaski, La & 55 & $4,9 \%-4,2 \%$ \\
Amite City, La & 16 & $1,4 \%-1,2 \%$ \\
Vidalia, La & 11 & $1,0 \%-0,8 \%$ \\
Waterproof, La & 10 & $0,9 \%-0,8 \%$ \\
Camp Moore, La & 8 & $0,7 \%-0,6 \%$ \\
Inne miejsca, La & 6 & $0,5 \%-0,5 \%$ \\
Richmond, Wirginia & 7 & $0,6 \%-0,5 \%$ \\
Inne miejsca, poza La & 10 & $0,9 \%-0,8 \%$ \\
\hline
\end{tabular}

Ogółem 14. regiment zasiliło odpowiednio: w 1861 r. - 1092 osoby (97,15\%), w 1862 r. - 31 osób (2,75\%), w 1863 r. - 1 żołnierz (0,10\%). Łącznie aż 916 żołnierzy zaciągnęło się w Nowym Orleanie, w pozostałych miejscowościach Luizjany uczyniło to 186 kolejnych, a 17 zarejestrowało się w innych stanach, głównie w Wirginii. Ponadto w wypadku 5 osób miejsce zaciągu pozostało nieznane.

Z 1296 żołnierzy opisywanej formacji 556 (42,9\%) podało swój wiek w momencie zaciągu. Nieco więcej, gdyż 618 (47,6\%) wyjawiło swój stan cywilny. Należy przy tym zauważyć, że łącznie wiek i stan cywilny ujawniło 528 z nich (40,7\%). Z kolei 90 (6,9\%) podało tylko stan cywilny, a $28(2,2 \%)$ jedynie wiek.

Z 528 żołnierzy, którzy podali obie informacje, 453 (85,8\%) pozostawało w stanie bezżennym (w większości byli to kawalerowie, chociaż zapewne znalazłoby się wśród nich kilku wdowców lub rozwodników), a 75 było żonatych $(14,2 \%)$. Ponadto wśród 90, którzy podali tylko stan cywilny znajdowało się 24 żonatych i 66 kawalerów. Ogółem stan cywilny jednostki pozostawał znany w wypadku 618 ludzi, w tym 519 kawalerów (84\%) i 99 żonatych (16\%). W stosunku do wszystkich żołnierzy pułku liczby te przekładały się odpowiednio na $40 \%$ i $7,6 \%$.

Z 556 żołnierzy, którzy ujawnili swój wiek, jak wspominałem, 453 stanowili kawalerowie (81,5\%), 75 - mężczyźni żonaci (13,5\%), a 28 kolejnych nie podało w tym zakresie żadnych danych (5\%). Średnia wieku dla mężczyzn, którzy nie określili swojego stanu cywilnego, wyniosła 28,9 lat, dla kawalerów - 25,5 lat, a dla żonatych - 31,1 lat. Z danych wynika, że mężczyźni żonaci wyróżniali się wśród innych żołnierzy 14. pułku piechoty z Luizjany średnią wieku przewyższającą kawalerów o blisko 5 lat. Ponadto można też zaryzykować stwierdzenie, że 
Tabela 3. Przekrój wiekowy żołnierzy z 14. pułku piechoty z Luizjany

\begin{tabular}{|c|c|c|c|}
\hline $\begin{array}{c}\text { Wiek w momencie } \\
\text { zaciągu }\end{array}$ & $\begin{array}{l}\text { Liczba } \\
\text { żołnierzy }\end{array}$ & $\begin{array}{c}\text { Wiek w momencie } \\
\text { zaciągu }\end{array}$ & $\begin{array}{l}\text { Liczba } \\
\text { żołnierzy }\end{array}$ \\
\hline 11 lat & 1 & 34 lata & 5 \\
\hline 14 lat & 1 & 35 lat & 27 \\
\hline 15 lat & 1 & 36 lat & 4 \\
\hline 16 lat & 5 & 37 lat & 1 \\
\hline 17 lat & 9 & 38 lat & 7 \\
\hline 18 lat & 20 & 39 lat & 1 \\
\hline 19 lat & 22 & 40 lat & 15 \\
\hline 20 lat & 39 & 41 lat & 4 \\
\hline 21 lat & 30 & 42 lata & 2 \\
\hline 22 lata & 42 & 43 lata & - \\
\hline 23 lata & 21 & 44 lata & 4 \\
\hline 24 lata & 52 & 45 lat & 5 \\
\hline 25 lat & 62 & 46 lat & 5 \\
\hline 26 lat & 36 & 47 lat & 1 \\
\hline 27 lat & 32 & 48 lat & 1 \\
\hline 28 lat & 35 & 49 lat & - \\
\hline 29 lat & 18 & 50 lat & 1 \\
\hline 30 lat & 23 & 51 lat & 1 \\
\hline 31 lat & 7 & 52 lata & 1 \\
\hline 32 lata & 12 & 60 lat & 1 \\
\hline 33 lata & 2 & & \\
\hline Przedział lat $11-19$ & $\begin{array}{l}59(10,6 \%) \\
\text { (4 żonatych) }\end{array}$ & Przedział lat $40-49$ & $\begin{array}{c}37(6,7 \%) \\
(13 \text { żonatych) }\end{array}$ \\
\hline Przedział lat $20-29$ & $\begin{array}{c}367(66 \%) \\
(32 \text { żonatych) }\end{array}$ & Przedział lat 50- & $\begin{array}{l}4(0,7 \%) \\
(1 \text { żonaty) }\end{array}$ \\
\hline Przedział lat 30-39 & $\begin{array}{c}89(16 \%) \\
(25 \text { żonatych) }\end{array}$ & & \\
\hline \multicolumn{4}{|c|}{ Nie podało wieku 740 osób $(53,1 \%)$} \\
\hline \multicolumn{4}{|c|}{ Średni wiek żołnierza pułku (556 osób) wynosił 26,5 lat } \\
\hline
\end{tabular}

wśród mężczyzn bez określonego stanu cywilnego znajdowało się przynajmniej kilku żonatych.

Ogółem przeciętny wiek żołnierza pułku wynosił w przybliżeniu 26,5 lat. Czy był to wiek miarodajny dla omawianego regimentu? Trudno do końca to stwierdzić ze względu na brak danych aż 53,1\% żołnierzy. Ponadto część zaciągniętych nastolatków mogła zawyżać swój rzeczywisty wiek z obawy przed 
odrzuceniem w momencie zaciągu. Przekrój wiekowy członków regimentu został przedstawiony w tabeli 3 .

Wszyscy żołnierze jednostki podali swoje nazwiska przy rejestracji. Spośród liter alfabetu jedynie litera „X” nie była reprezentowana przez członków regimentu. Najwięcej nazwisk rozpoczynało się na literę „M" - 194 (15\%), co było po części związane z irlandzkim charakterem pułku. Liczne były też nazwiska zaczynające się na litery: „C” - 129; „B” - 120; ,S” - 109; „H” - 105. Na przeciwnym biegunie znajdowały się litery takie jak: „U”- 3; „I”, „Y”- 4; „Q”- 5; „V" - 6. Liczby żołnierzy przyporządkowane pierwszym literom nazwisk można odnaleźć w tabeli 4.

Tabela 4. Pierwsze litery nazwisk żołnierzy 14. pułku piechoty z Luizjany

\begin{tabular}{|c|c|c|c|c|c|}
\hline $\begin{array}{c}\text { Pierwsza } \\
\text { litera } \\
\text { nazwiska }\end{array}$ & $\begin{array}{c}\text { Liczba } \\
\text { zołnierzy }\end{array}$ & $\begin{array}{c}\text { Pierwsza } \\
\text { litera } \\
\text { nazwiska }\end{array}$ & $\begin{array}{c}\text { Liczba } \\
\text { żołnierzy }\end{array}$ & $\begin{array}{c}\text { Pierwsza } \\
\text { litera } \\
\text { nazwiska }\end{array}$ & $\begin{array}{c}\text { Liczba } \\
\text { żołnierzy }\end{array}$ \\
\hline A & 24 & $\mathrm{~J}$ & 26 & $\mathrm{~S}$ & 109 \\
$\mathrm{~B}$ & 120 & $\mathrm{~K}$ & 63 & $\mathrm{~T}$ & 32 \\
$\mathrm{C}$ & 129 & $\mathrm{~L}$ & 41 & $\mathrm{U}$ & 3 \\
$\mathrm{D}$ & 70 & $\mathrm{M}$ & 194 & $\mathrm{~V}$ & 6 \\
$\mathrm{E}$ & 19 & $\mathrm{~N}$ & 23 & $\mathrm{~W}$ & 72 \\
$\mathrm{~F}$ & 52 & $\mathrm{O}$ & 31 & $\mathrm{X}$ & - \\
$\mathrm{G}$ & 60 & $\mathrm{P}$ & 48 & $\mathrm{Y}$ & 4 \\
$\mathrm{H}$ & 105 & $\mathrm{Q}$ & 5 & $\mathrm{Z}$ & 8 \\
$\mathrm{I}$ & 4 & $\mathrm{R}$ & 47 & & \\
\cline { 5 - 5 } & & & & &
\end{tabular}

$\mathrm{Z}$ kolei pełne imiona (przynajmniej pierwsze z nich) podało 1104 żołnierzy $(85,2 \%)$. Pozostałych $192(14,8 \%)$ ujawniło tylko pierwsze litery imion. Zdecydowaną przewagę miały imiona zaczynające się na literę „J” - $411(31,7 \%)$. Żołnierze, którzy posiadali imię zaczynające się na tę literę, nosili przynajmniej 14 rozmaitych imion: John, James, Jacob, Joseph, Jeremiah, Jasper, Jules, Jerry, Justin, Joel, Justis, Jackson, Jonathan, Jesse. Z drugiej strony cztery litery: „K”, „Q”, „X” i „Y” nie występowały w spisie pierwszych liter imion.

Mężczyźni z 14. pułku nosili 138 różnych imion. Najpopularniejszym z nich było imię John (198 - przynajmniej 15,3\%) ${ }^{19}$, wyraźnie ustępowały mu imiona James $(103-7,9 \%)$ i William $(98$ - 7,6\%). Więcej szczegółów można znaleźć w tabeli 6 .

19 W 31. pułku piechoty z Nowego Jorku, w którym służyło około 40 Polaków, najczęściej spotykane (164) również było imię John - Ł. Niewiński, Polacy z 31. pułku..., s. 123. 
Tabela 5. Pierwsze litery imion żołnierzy 14. pułku piechoty z Luizjany

\begin{tabular}{|c|c|c|c|c|c|}
\hline $\begin{array}{c}\text { Pierwsza } \\
\text { litera } \\
\text { imienia }\end{array}$ & $\begin{array}{c}\text { Liczba } \\
\text { żołnierzy } \\
\text { (liczba imion) }\end{array}$ & $\begin{array}{c}\text { Pierwsza } \\
\text { litera } \\
\text { imienia }\end{array}$ & $\begin{array}{c}\text { Liczba } \\
\text { żołnierzy } \\
\text { (liczba imion) }\end{array}$ & $\begin{array}{c}\text { Pierwsza } \\
\text { litera } \\
\text { imienia }\end{array}$ & $\begin{array}{c}\text { Liczba } \\
\text { żołnierzy } \\
\text { (liczba imion) }\end{array}$ \\
\hline A & 44 (14) & $\mathrm{J}$ & $411(14)$ & $\mathrm{S}$ & $29(4)$ \\
\hline B & $24(5)$ & $\mathrm{K}$ & - & $\mathrm{T}$ & 97 (6) \\
\hline $\mathrm{C}$ & $63(10)$ & $\mathrm{L}$ & $23(9)$ & $\mathrm{U}$ & $1(1)$ \\
\hline D & $34(6)$ & M & $103(14)$ & V & $6(6)$ \\
\hline $\mathrm{E}$ & $54(7)$ & $\mathrm{N}$ & $14(3)$ & W & $107(3)$ \\
\hline $\mathrm{F}$ & 41 (4) & $\mathrm{O}$ & 7 (2) & $X$ & - \\
\hline G & $43(3)$ & $\mathrm{P}$ & $79(8)$ & Y & - \\
\hline $\mathrm{H}$ & $63(7)$ & Q & - & $\mathrm{Z}$ & $3(2)$ \\
\hline I & $4(3)$ & $\mathrm{R}$ & $46(7)$ & & \\
\hline
\end{tabular}

Tabela 6. Dwadzieścia cztery najpopularniejsze imiona noszone przez żołnierzy 14. pułku piechoty z Luizjany

\begin{tabular}{|c|c|c|c|c|c|}
\hline Imię & $\begin{array}{c}\text { Liczba } \\
\text { żołnierzy } \\
(\%)\end{array}$ & Imię & $\begin{array}{c}\text { Liczba } \\
\text { żołnierzy } \\
(\%)\end{array}$ & Imię & $\begin{array}{c}\text { Liczba } \\
\text { żołnierzy } \\
\quad \%)\end{array}$ \\
\hline 1. John & 198 & 9. George & 34 & ... Samuel & 12 \\
\hline 2. James & 103 & 10. Edward & 30 & 18. Jacob & 11 \\
\hline 3. William & 98 & 11. Joseph (Joe) & 26 & ... Martin & 11 \\
\hline 4. Thomas & 72 & 12. Peter & 18 & ... Richard & 11 \\
\hline 5. Michael & 58 & ... Robert & 18 & 21. Louis (Lewis) & 10 \\
\hline 6. Henry & 48 & 14. Francis (Frank) & 14 & ... Nicholas & 10 \\
\hline 7. Charles & 36 & 15. Frederick (Fred) & 13 & ... Timothy & 10 \\
\hline ... Patrick & 36 & 16. Daniel & 12 & 24. Benjamin & 9 \\
\hline
\end{tabular}

Interesująco przedstawia się podział żołnierzy według kryteriów zawodowych. $641 \mathrm{z}$ nich $(49,4 \%)$ podało w momencie rejestracji (lub później podczas pobytu w niewoli Unii) wykonywany zawód. Przeważali wśród nich robotnicy - 301. Licznie reprezentowani byli również urzędnicy (70), farmerzy (59), cieśle (45), marynarze (18), malarze pokojowi (12) i szewcy (10).

Łącznie członkowie pułku reprezentowali przynajmniej 60 różnych zawodów, takich jak: plantator (8), inżynier (7), garncarz (7), tynkarz (6), załogant parowca (5), nadzorca niewolników? (5), murarz (4), maszynista lub operator maszyny (4), bednarz (4), lekarz (3), prawnik (3), cukiernik (3), rzeźnik (3), ogrodnik (3), fryzjer (3), krawiec (3), poganiacz (ujeżdżacz?) byków (2), mierniczy (2), kupiec (2), kowal (2), jubiler (2); a także reprezentowani jednoosobowo: 
architekt, policjant, wytwórca lin okrętowych, aptekarz, właściciel baru, zawodowy hazardzista, introligator, napełniacz lamp gazowych, młynarz, nauczyciel, wycinacz kamieni, makler giełdowy i rusznikarz.

Wyraźnie da się też zauważyć związek zachodzący między lepszym wykształceniem a uzyskiwaniem stopni oficerskich. Znane są bowiem zawody 34 (z ogólnej liczby 106) oficerów pułku. I tak szarże te uzyskało - 15 urzędników; po 3 - inżynierów, plantatorów i farmerów; po 2 - lekarzy, kupców i prawników oraz po 1 - nadzorcy, policjancie, mierniczym i (tylko 1) robotniku.

Miejsce urodzenia podało 666 żołnierzy regimentu (51,3\%). Poza granicami USA urodziło się $376 \mathrm{z}$ nich $(56,46 \%$ oraz $29 \%$ całkowitego stanu osobowego jednostki), a na terytorium amerykańskim 290 (43,54\% oraz 22,37\% całkowitego stanu osobowego jednostki). Spośród reprezentantów 13 innych narodowości najwięcej było Irlandczyków - 249. Tylko dwóch z nich precyzyjniej określiło miejsce urodzenia, dodając nazwy miast - Dublin i Limerick. Ponadto 83 kolejnych pochodziło z Niemiec, w tym przynajmniej $1 \mathrm{z}$ Bawarii. Inne państwa były reprezentowane przez o wiele skromniejszą liczbę żołnierzy, np. Anglia (14), Francja (9), Kanada (8). Interesujące, że badane przeze mnie dokumenty źródłowe nie wzmiankują nic o tożsamości Polaków w 14. pułku z Luizjany. Jednak w wypadku kilku z nich mamy pewność, a w niektórych innych wypadkach możemy się domyślać, że urodzili się w Polsce lub mieli polskie pochodzenie ${ }^{20}$. W wypadku niniejszej jednostki tak się złożyło, że jej twórca - Kacper Tochman i pierwszy dowódca - Walery Sulakowski byli Polakami. I tylko z tego względu przyjęła się, prawdopodobnie lansowana przez nich, nazwa „Polish Regiment”. W rzeczywistości o wiele bardziej do tej jednostki pasowałaby nazwa pułku irlandzkiego. Irlandczycy stanowili przecież aż 37,4\% żołnierzy, którzy podali miejsce urodzenia i 19,2\% stanu całego pułku. Nie należy przy tym zapominać, że procent ów niewątpliwie jeszcze by się zwiększył (prawdopodobnie do ok. 40\%), gdyby było nam dane poznać miejsce urodzenia wszystkich żołnierzy. Szczegółowe dane dotyczące miejsca urodzenia znajdują się w tabeli 7.

290 członków jednostki podało jako miejsce urodzenia poszczególne stany USA. W 14 stanach południowych przyszło na świat 215 osób. Ze stanów niewolniczych jedynie Floryda nie posiadała swojego reprezentanta. Najwięcej urodziło się w Luizjanie - 138. Z kolei w 11 stanach północnych ujrzało światło dzienne 75 żołnierzy, w tym w Nowym Jorku - 24. Szczegółowy rozkład miejsc narodzin żołnierzy został zamieszczony w tabeli 8 .

20 Byli to oficerowie - Kacper Tochman, Walery Sulakowski i Władyslaw Wańkowicz oraz prawdopodobnie żołnierze: J. Kalinowski, Michał Kamiński, Franciszek Krasicki, Jan Krombek, Józef Roman, Paweł Zygmunt. Ogółem polskie pochodzenie można było przypisać maksymalnie 22 żołnierzom jednostki - w rzeczywistości było ich jeszcze mniej - Ł. Niewiński, Brygada Polska..., s. $239,244-249$. 
Tabela 7. Miejsce urodzenia obcokrajowców służących w 14. pułku piechoty z Luizjany

\begin{tabular}{|l|c|l|c|}
\hline Nazwa kraju & $\begin{array}{c}\text { Liczba } \\
\text { żołnierzy }\end{array}$ & Nazwa kraju & $\begin{array}{c}\text { Liczba } \\
\text { żołnierzy }\end{array}$ \\
\hline Irlandia & 249 & Belgia & 1 \\
Niemcy & 83 & Norwegia & 1 \\
Anglia & 14 & Szwecja & 1 \\
Francja & 9 & Dania & 1 \\
Kanada & 8 & Włochy & 1 \\
Szwajcaria & 4 & Sycylia & 1 \\
Szkocja & 3 & Ogółem & 376 \\
\hline
\end{tabular}

Tabela 8. Wykaz stanów południowych i północnych, w których urodzili się żołnierze 14. pułku piechoty z Luizjany

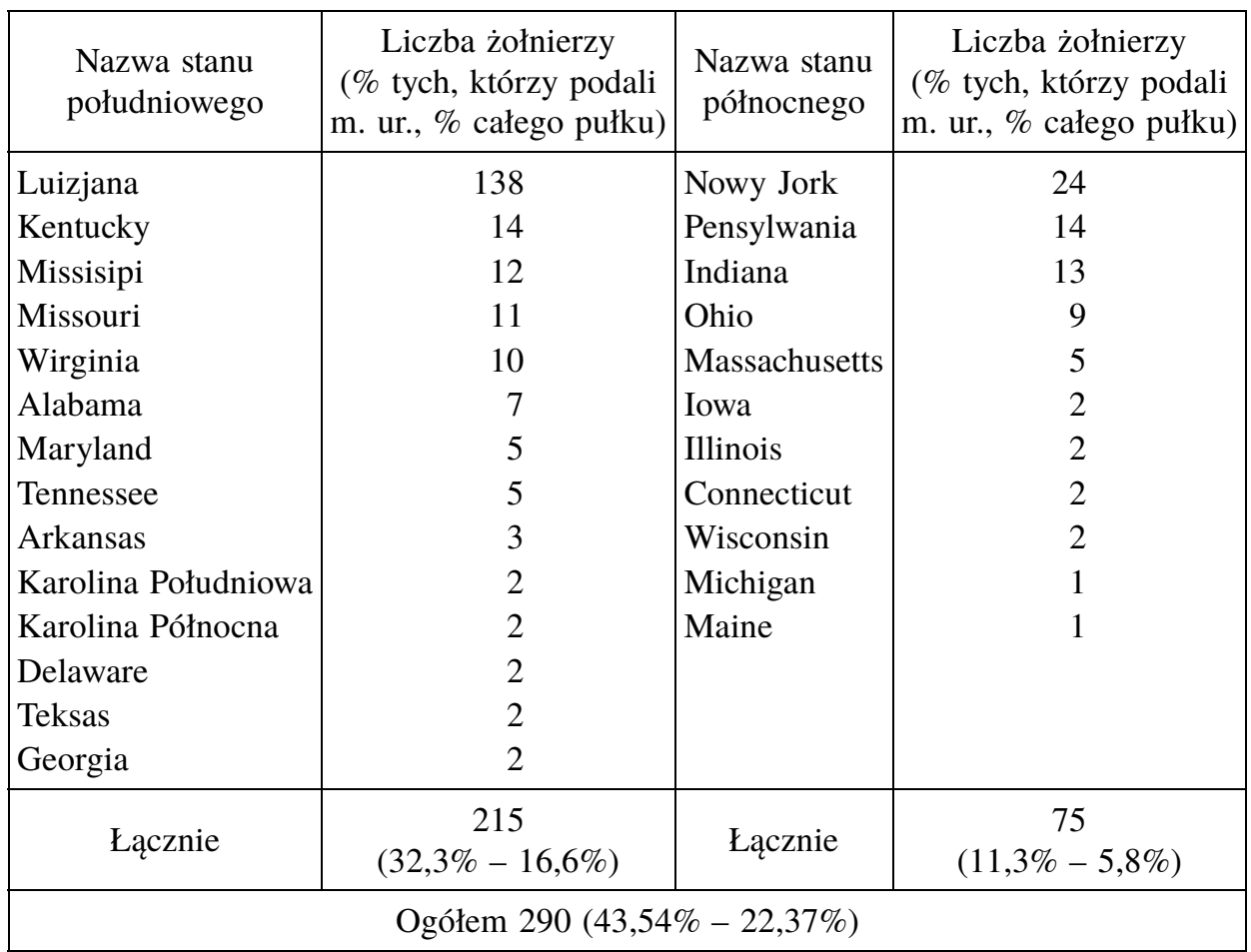

Miejsce zamieszkania ujawniła dokładnie połowa żołnierzy pułku (648). Aż 456 z nich rezydowało w Nowym Orleanie - największym mieście Luizjany. Kolejnych 158 również zamieszkiwało na terenie tego stanu, w tym w poszcze- 
gólnych parafiach i miastach, m.in. w: Penhook (64), Concordia (32), Thibodaux (22), Pointe Coupee (17), Tensas (5), Franklin (3). Łącznie 614 osób rezydowało na terenie Luizjany. Poza nią zamieszkiwało jedynie 34 żołnierzy z czego 22 w mieście Natchez (Missisipi).

Należy dodać, że kilkunastu dezerterów, którzy w niewoli federalnej podpisali przysięgę na wierność USA, aby pozostać na Północy, musiało w wypełnianych dokumentach zamieścić nieprawdziwe dane dotyczące zamieszkania, m.in. Nowy Jork, Filadelfia, Detroit, Chicago, itp. Takowi delikwenci, jeżeli w innych dokumentach nie podali prawdziwych danych, nie byli brani pod uwage w obliczeniach statystycznych.

Szczegółowe dane osobowe, dotyczące wyglądu zewnętrznego podawali głównie jeńcy konfederaccy, gdyż władze Unii tego od nich wymagały. Na wygląd zewnętrzny składał się opis 4 cech - cery (dane podane w stosunku do 98 żołnierzy 14. pułku - 7,5\%), koloru włosów (98), koloru oczu (97) i wzrostu (94). U żołnierzy 14. pułku wyróżniono przynajmniej 6 rodzajów cery: ciemną (dark - 47), przeciętnie jasną (fair - 22), świetliście jasną (light - 17), rumianą w różnych odcieniach (florid, ruddy - 9), ziemistą o żółtym odcieniu (sallow - 2), rudoblond (sandy - 1). Większość jeńców posiadała ciemne włosy (40), pozostali byli właścicielami włosów: jasnych (21), brązowych (17), czarnych (13), kasztanowych (3), rudoblond (2), siwych (1) i rudych (1). Kolor oczy żołnierzy regimentu był przeważnie niebieski (30) lub szary (29), nieco rzadziej piwny (20) lub ciemny (10). Wyjątkowo spotykano właścicieli oczu czarnych (5) albo brązowych (3). Przeciętny wzrost 94 żołnierzy, u których zamieszczono takowe dane, wynosił 172,8 cm. Mniej niż $160 \mathrm{~cm}$ mierzyło 3 żołnierzy. Wzrost od $160 \mathrm{~cm}$ do $170 \mathrm{~cm}$ posiadało 21 członków pułku. W przedziale między $170 \mathrm{~cm}$ a $180 \mathrm{~cm}$ mieściła się większość żołnierzy (60), pozostałych 10 mierzyło ponad $180 \mathrm{~cm}$.

Przez okres funkcjonowania jednostki służyło w niej przynajmniej 106 oficerów. Siedem stanowisk oficerów sztabowych (pułkownik, podpułkownik, major, adjutant, lekarz, asystent lekarza i kapelan) zajmowało minimum 20 ludzi (w tym 5 pochodzących $z$ awansu). Od trzydziestu do czterdziestu etatów oficerów liniowych (kapitan, porucznik, podporucznik, ew. 3. porucznik - x 10 kompanii) obsadzało przez okres wojny 91 ludzi, z czego 5 awansowało na etaty oficerów sztabowych. Oficerowie jednostki skwapliwie korzystali z przysługującej im możliwości rezygnacji z armii. $\mathrm{Z}$ takiej opcji skorzystało aż 33 oficerów (31\%). W 1861 r. zrezygnowało 15 oficerów w tym aż 7 uczyniło to we wrześniu. Decyzje te były powiązane $\mathrm{z}$ buntem w Grand Junction (Tennessee) w sierpniu 1861 r., a przynajmniej 5 oficerów z powodu własnej niekompetencji zostało zmuszonych do rezygnacji z armii przez sekretarza wojny Konfederacji. W kolejnym roku taką samą decyzję podjęło 14 dalszych oficerów z pierwszym dowódcą pułku - Walerym Sulakowskim na czele (19 lutego). Prawie połowa z nich (6) uczyniła to na przełomie lutego i marca. Ostatnie potwierdzone w dokumentach rezygnacje (4) miały miejsce w 1863 r. Najwięcej oficerów zrezygnowało we 
wrześniu (7 - wszyscy w 1861 r.) oraz grudniu (5). Z kolei w kwietniu i maju nie została złożona żadna rezygnacja. Zrezygnowało łącznie 6 oficerów sztabowych (1 pułkownik, 1 podpułkownik, 2 lekarzy, 1 asystent lekarza i 1 kapelan) oraz 27 oficerów liniowych (14 kapitanów, 7 poruczników, 6 podporuczników). Szczegółowe losy oficerów zostały przedstawione w tabeli 9. Do głównych przyczyn rezygnacji ze służby należały: zmęczenie trudami kampanii, dolegliwe rany, choroby, itp.

Tabela 9. Losy oficerów 14. pułku piechoty z Luizjany

\begin{tabular}{|l|c|c|}
\hline \multicolumn{1}{|c|}{ Nazwa zdarzenia } & $\begin{array}{c}\text { Liczba } \\
\text { oficerów }\end{array}$ & $\begin{array}{c}\% \\
\text { (ze 106 oficerów) }\end{array}$ \\
\hline Zrezygnowali & 33 & $31,1 \%$ \\
\hline Zdymisjonowani, zwolnieni & 1 & $0,9 \%$ \\
\hline Ranni & 27 & $25,5 \%$ \\
\hline Zmarli z ran bądź chorób & 7 & $6,6 \%$ \\
\hline Zabici & 6 & $5,7 \%$ \\
\hline Dezerterzy (lub samowolnie oddalili się) & 8 & $7,5 \%$ \\
\hline Jeńcy & 15 & $14,2 \%$ \\
\hline Zwolnieni na parol (Appomattox) & 2 & $1,9 \%$ \\
\hline $\begin{array}{l}\text { Zwolnieni z obozów jenieckich po } \\
\text { podpisaniu przysięgi wierności USA }\end{array}$ & 4 & $3,8 \%$ \\
\hline Brak wiadomości & 24 & $22,6 \%$ \\
\hline Sądzeni przez sądy polowe & 7 & $6,6 \%$ \\
\hline
\end{tabular}

W trakcie działań wojennych z jednostki zostało zwolnionych 105 ludzi $(8,1 \%$ ogólnego stanu osobowego). W porównaniu do innych regimentów Konfederacji nie był to wysoki procent. W dziejach pułku dwa razy zbierała się komisja lekarska, która przebadała i wydała orzeczenia dotyczące zwolnień ze służby. Pierwszy raz komisja zebrała się 20 lipca 1861 r. i wydała przynajmniej 14 certyfikatów żołnierzom niezdatnym do służby frontowej. Po raz drugi przebadano pozostałych przy życiu żołnierzy po bitwie pod Sharpsburgiem (17 września) na przełomie września i października 1862 r. Ponownie lekarze wydali 20 certyfikatów zdrowotnych zwalniających żołnierzy z dalszej służby. W następnych latach prawdopodobnie nie doszło już do takich egzaminów lekarskich. Od końca 1862 r. praktyką w armii Konfederacji stało się odsyłanie ludzi poważnie rannych, chorych bądź inwalidów do dalszej służby pomocniczej na tyłach, gdzie pełnili funkcje pielęgniarzy w szpitalach, żandarmów, wartowników, itp. Rozkład zwol- 
nień przedstawiał się następująco: w 1861 r. zwolniono 18 ludzi, w 1862 r. - 53, w 1863 r. - 10, w 1864 r. - 6, w 1865 r. - 2. Z każdym kolejnym rokiem zwolnień było mniej, głównie z tego powodu, że jednostka wskutek strat osobowych poniesionych w licznych bitwach skurczyła się do rozmiarów kompanii.

Głównymi powodami zwolnień były: inwalidztwo - 42, wiek - 17 (w tym 11 z powodu niepełnoletności), niezdolność do dalszego pełnienia służby - 9, rany -5 , zwolnienie honorowe -3 , zamieszki z 1861 r. -2 , choroba -1 , amputacja -1 , głuchota -1 , dostarczenie zastępcy (substytuta) -1 . W pozostałych 23 wypadkach przyczyna zwolnienia nie została podana.

Najwięcej żołnierzy zwolniono z kompanii I - 17. Z pozostałych kompanii zwolniono odpowiednio: $\mathrm{H}-14$; E, F, K - 13; C, D - 8; B - 7; A, G - 4 . W wypadku 2 osób nie udało się zidentyfikować kompanii, w której służyli przed zwolnieniem.

Przez okres funkcjonowania jednostki zdezerterowało z niej 280 żołnierzy $(21,6 \%)$. Ponadto w wypadku kolejnych 39 pojawiają się wątpliwości co do ewentualnej ucieczki. W stosunku do nich w dokumentach nie została bowiem wprost wskazana dezercja, a jedynie domyślnie inne powody, jak np. samowolne oddalenie się (absent without leave), zaginięcie, skierowanie do innej służby czy dostanie się do niewoli federalnej. Wskaźnik dezercji w 14. pułku piechoty z Luizjany nie odbiegał, jak się wydaje, znacząco od wskaźników innych pułków wojsk konfederackich. Niestety nie znamy przeciętnej liczba dezerterów w pułkach armii Południa.

Aż 44 uczyniło to już w 1861 r., głównie w czerwcu i lipcu. Dezercji sprzyjała okoliczność kwaterowania pułku w pobliżu dużej aglomeracji miejskiej, jaką stanowił Nowy Orlean. Miasto zapewniało możliwość stosunkowo łatwej ucieczki i ukrycia się. Dezercjom sprzyjał też bałagan organizacyjny oraz brak dyscypliny. Przynajmniej 6 żołnierzy pożegnało jednostkę w trakcie podróży do Wirginii, zapewne w trakcie zamieszania w Grand Junction. Symptomatyczne, że najwięcej dezerterów (169) uciekło z pułku w 1862 r., kiedy to jednostka w ciągu kilku miesięcy (maj-wrzesień) wzięła udział w bardzo krwawych dla niej bitwach. Wraz ze zmniejszaniem się stanu osobowego zmniejszała się też systematycznie liczba dezerterów. W 1863 r. zdezerterowało 64 ludzi, w roku następnym - 31, a w ostatnich miesiącach wojny -7 .

Dezerterów można było podzielić na dwie grupy. Większa część z nich udawała się do własnych domów na Południe (208). Mniejsza część wybrała daleko bardziej niebezpieczną w skutkach dezercję do wroga (72). W $1862 \mathrm{r}$. uczyniło to 32 ludzi, w 1863 r. - 13, w 1864 r. - 21, a w 1865 r. - 6.

Należy zauważyć, że do końca 1863 r. zdecydowanie przeważali dezerterzy z pierwszej grupy. Sytuacja ta zaczęła się zmieniać od 1864 r. Z 37 dezerterów, aż 27 uciekło do wroga. Prawdopodobnie było to spowodowane zwiększoną kontrolą w stosunku do dezerterów w armii Południa oraz coraz mniejszym terytorium Konfederacji. 
Żołnierze uciekali głównie podczas wielkich bitew, np. pod Williamsburgiem (5-6 maja 1862 r.) tylko do wroga uciekło przynajmniej 15 żołnierzy. Kolejnych 7 uczyniło to pod Gettysburgiem (1-3 lipca 1863 r.), a 5 pod Chancellorsville (1-4 maja 1863 r.). Innym popularnym miejscem ucieczki okazywał się (przynajmniej w latach 1862-1863) szpital, z którego w trakcie odbywania rekonwalescencji uciekło przynajmniej 12 osób. Zapewne najwięcej żołnierzy jednostki nie powróciło do niej po zakończeniu urlopów, na które byli wysyłani do Luizjany przeważnie w okresach zimowych. Należy tu jednak dodać, że część stanu znajdowała się od połowy 1862 r. w rękach oddziałów federalnych i nie można do końca stwierdzić ilu żołnierzy faktycznie zdezerterowało a ilu nie mogło powrócić do własnego regimentu lub zostało wziętych do niewoli. W styczniu i lutym 1864 r. dezercja do wroga nasiliła się. W okresie tym uciekło poza linie nieprzyjaciela 14 żołnierzy. Wszyscy uczynili to między 24 stycznia, a 18 lutego w okolicach Rapidan Bridge w Wirginii. Przynajmniej część z tych dezercji wiązała się z utratą (kradzieżą?) pułkowego magazynu z bronią, a dezerterzy zapewne obawiali się pociągnięcia do odpowiedzialności.

Na pewien plus można dezerterom z 14. pułku można zaliczyć to, że 24 z nich powróciło do macierzystej jednostki. Ponadto 44 kolejnych zdezerterowało, aby dołączyć do innych oddziałów Południa, co nie było aż tak haniebnym uczynkiem jak zwykła ucieczka. Szczególną estymą cieszyła się kawaleria, w której służba według powszechnego mniemania żołnierzy Konfederacji była lżejsza niż w piechocie. Do jednostek kawalerii zaciągnęło się 34 dezerterów z 14. pułku. Kolejnych 10 przyłączyło się do artylerii, marynarki wojennej lub innych niezidentyfikowanych oddziałów. Zdezerterowało lub samowolnie oddaliło się od jednostki również 8 oficerów. Warto wspomnieć, że 11 żołnierzy regimentu dezerterowało przynajmniej dwa razy, a rekordzista, Conrad Firing szeregowiec kompanii K, uciekał trzykrotnie.

Przynajmniej 20 dezerterów zostało ujętych przez oddziały żandarmerii i odstawionych pod strażą do macierzystej jednostki. Zamknięci w areszcie (guard house) oczekiwali na proces przed sądem polowym. Groźniejszych przestępców skazywano na pobyt w obozie Castle Thunder w Richmond, który cieszył się złą sławą w armii Konfederacji ze względu na panujące w nim bardzo ciężkie warunki i brutalną straż. O tym ostatnim boleśnie przekonał się Charles Bernard szeregowiec kompanii C 14. pułku, który został zastrzelony przez strażnika.

36 żołnierzy (w tym 7 oficerów) 14. pułku z Luizjany stanęło przed sądami polowymi. John Delahide szeregowiec kompanii F stawał przed takim sądem dwukrotnie. $Z$ oskarżonych aż 1/3 odpowiadała za dezercję lub samowolne oddalenie się. Pozostali naruszali postanowienia artykułów wojny, sprzeciwiali się wykonywaniu rozkazów przełożonych, wykazywali niesubordynację i brak szacunku w stosunku do oficerów, tchórzostwo oraz kradli i pili na służbie. W 1/3 wypadków oskarżonych żołnierzy uniewinniono. Sądy polowe wydały dwa wyroki śmierci na żołnierzy 14. pułku. Za dezercję skazano Johna Balsera, 
szeregowca kompanii K. Wyrok nie został jednak wykonany, gdyż w międzyczasie wspomniany Balser został zwolniony z aresztu i dostał się do niewoli federalnej. Mniej szczęścia miał Terry O’Connell, sierżant kompanii F, który pod koniec 1862 r. został rozstrzelany, prawdopodobnie również za dezercję. Pozostali oskarżeni zostali skazani na kary: więzienia $(6-\mathrm{w}$ areszcie, $w$ tym o chlebie i wodzie lub w Castle Thunder w zależności od rangi przestępstwa), ciężkich robót połączonych z karą więzienia (9), lżejszych kar kompanijnych (3) czy na wydalenie ze służby (1). Z 7 oficerów, którzy stanęli przed sądem, 4 zostało uniewinnionych, 1 zawieszony w sprawowaniu obowiązków, 1 za samodzielne oddalenie się od pułku został ukarany reprymendą, a ostatniego - Williama Dobsona porucznika kompanii I - wydalono ze służby 4 marca 1863 r. $^{21}$

Według opracowywanych źródeł 138 żołnierzy pułku zostało zabitych $(10,6 \%)$. Największe straty jednostka poniosła w swoich trzech pierwszych bitwach, stoczonych między 5 maja a 30 czerwca 1862 r: pod Williamsburgiem - 27 zabitych, pod Gaines' Mill - 28 zabitych i pod Frayser's Farm - 23 zabitych. Większość pozostałych strat pułk poniósł między sierpniem 1862 r., a grudniem 1863 r. Przyczyniły się do nich głównie - kampania 2nd Manassas - 12 zabitych oraz bitwy: pod Sharpsburgiem -7 zabitych, Chancellorsville -5 zabitych, Gettysburgiem - 10 zabitych i Payne's Farm - 6 zabitych. W latach 1864-65, czyli najkrwawszym okresie wojny secesyjnej, pułk tracił już tylko pojedynczych zabitych. Ogółem w 1862 r. zginęło 99 ludzi, w 1863 r. - 22, w 1864 r. - 11, a 6 straciło życie wskutek innych zdarzeń losowych.

Ze 138 znanych z tożsamości zabitych na poszczególne kompanie przypadało: F - 18, A - 17, B i K - po $16, \mathrm{E}-15, \mathrm{H}-13$, C i D - po 12 , I - 11 oraz $\mathrm{G}-5$. Pozostałych 3 zabitych żołnierzy nie zostało przypisanych do konkretnej kompanii.

$\mathrm{W}$ trakcie wojny zmarło przynajmniej 115 żołnierzy pułku $(8,87 \%)$. Z powodu ran odniesionych w bitwach zmarło 37 osób. Ponadto 28 żołnierzy zmarło wskutek chorób. W 9 wypadkach znamy przyczynę ich zgonu. Były to: odra (4), zapalenie płuc (2), tyfus (2) i ospa (1). Kolejnych 19 osób oddało ducha w niewoli federalnej, z czego $10 \mathrm{w}$ szpitalach wskutek ran, a pozostałych $-9 \mathrm{w}$ obozach jenieckich wskutek chorób ${ }^{22}$. Ranni jeńcy umierali głównie po dwóch bitwach: pod Williamsburgiem (3) i pod Getysburgiem (5). Spośród jeńców zmarłych z chorób, zgony wszystkich nastąpiły po lipcu 1863 r., a więc już po zawieszeniu ich wymiany, w następujących obozach jenieckich: Elmira (3), Fort Delaware (3),

\footnotetext{
21 Wszystkie dane na podstawie: J. A. Bunch, Roster of the Courts-Martial in the Confederate States Army, Shippensburg, PA 2001; NARA, M 320 Compiled Service Records..., roll 0253-0263; Records of Louisiana Confederate..., vol. I-III.

$22 \mathrm{Na}$ podst: Register of Confederate Soldiers and Sailors Who Died in Federal Prisons and Military Hospitals in the North, reprint, pod red. F. Ingmire, C. Ericson, Nacogdoches, TX 1994.
} 
Point Lookout (1), Old Capitol Prison (1), Camp Morton (1). W rejestrach pułku odnotowano również 3 wypadki zgonów wskutek postrzałów odniesionych w trakcie buntu w Grand Junction oraz 1 utonięcie. Nie podano przyczyny śmierci 27 osób.

W 78 wypadkach znamy dzienną datę śmierci żołnierzy 14. regimentu z Luizjany. W $1861 \mathrm{r}$. zmarło 23 ludzi. Rok później liczba ta uległa podwojeniu (46). W 1863 r. zmarły 22 osoby, a w 1864 r. kolejnych 10. Przy 14 nazwiskach data śmierci pozostaje nieznana, podobnie jak i dane dotyczące $1865 \mathrm{r}$. Żołnierze najczęściej umierali w lipcu 1862 r. - 16, grudniu 1861 r. - 8, maju 1862 r. -7 oraz w sierpniu 1861 r. i wrześniu 1862 r. - po 6. Zwiększona umieralność żołnierzy była spowodowana w tych wypadkach głównie wcześniej stoczonymi bitwami. Na 115 żołnierzy miejsce zgonu zostało udokumentowane w 74 wypadkach. Najwięcej ludzi zmarło w szpitalach w Richmond (27), w niewoli (19), Ship Point (8), Luizjanie (4). Ponadto żołnierze 14. pułku umierali w innych miejscowościach stanu Wirginia, takich jak: Guinea Station, Liberty, Lynchburg, Middleburg, Petersburg, Staunton, Williamsburg, Yorktown. Pod względem liczby zmarłych przodowała kompania I -25 . Następne w kolejności były kompanie: A - 22, B - 15, F i K - po $11, \mathrm{H}-8, \mathrm{E}-6, \mathrm{G}-5, \mathrm{D}-4$, $\mathrm{C}-2,(?)-6$.

W wojnie secesyjnej rannych zostało przynajmniej 299 żołnierzy 14. pułku (23\%). Odnieśli oni 338 ran. Przynajmniej 2 rany odnotowano u 27 osób. Trzykrotnie rannych zostało 3 żołnierzy, a co najmniej 4 rany odniosło 2 oficerów - Enoch Farmer porucznik kompanii I - ranny w bitwach pod: Gaines' Mill 27 czerwca 1862 r., Fredericksburgiem w grudniu 1862 r., Gettysburgiem w lipcu 1863 r. i Payne's Farm 27 listopada 1863 r.; a także Thomas White porucznik kompanii C, ranny w maju lub czerwcu 1862 r., pod Sharpsburgiem 17 września 1862 r., w dolinie Shenandoah we wrześniu 1864 r., oraz w jeszcze jednej niezidentyfikowanej bitwie. Pierwszych trzech żołnierzy zostało rannych w potyczkach już w kwietniu 1862 r. Ogółem w 1862 r. ranne zostały 242 osoby (71,6\% wszystkich rannych), w 1863 r. - 77 (22,8\%), w 1864 r. - 12 (3,5\%), w wypadku $7(2,1 \%)$ data zranienia pozostaje nieznana. Blisko $87 \%$ wszystkich ran została odniesiona w trakcie kampanii półwyspowej, kampanii 2nd Manassas oraz bitew pod Sharpsburgiem, Chancellorsville i Gettysburgiem, czyli w okresie od maja 1862 r. do początków lipca 1863 r.

W dostępnych źródłach brakuje danych dotyczących liczby rannych z lat: 1861 i 1865. Spośród rannych przynajmniej 42 zostało inwalidami, a 37 zmarło. Żołnierzom amputowano nogi, ręce (5), palce, stopy; tracili wzrok, słuch, uzębienie. Rozkład sumy wszystkich odniesionych (znanych) ran na żołnierzy poszczególnych kompanii przedstawia się następująco: A - 39, F - 37, B i C - 35, $\mathrm{K}-33, \mathrm{E}-32, \mathrm{H}-28, \mathrm{I}-24, \mathrm{G}-20, \mathrm{D}-13$, (?) - 3 .

W trakcie konfliktu do niewoli Unii trafiło co najmniej 350 żołnierzy 14. pułku (27\%). Aż 35 z nich taka sztuka ,udała się" dwukrotnie. Ponadto 5 żoł- 
nierzy trzykrotnie zostało wziętych do niewoli federalnej. Łącznie pod władzę przeciwnika trafiali 395 razy. Schwytanych zostało 15 oficerów, w tym 3 z nich było zakładnikami służącymi jako ,żywe tarcze"23.

Tabela 10. Liczba wziętych do niewoli i wymienionych żołnierzy 14. pułku piechoty z Luizjany

\begin{tabular}{|c|c|c|c|}
\hline Rok & $\begin{array}{c}\text { Wzięci } \\
\text { do niewoli }\end{array}$ & Wymienieni & $\begin{array}{c}\text { Procent } \\
\text { wymienionych }\end{array}$ \\
\hline 1862 & 88 & 53 & $60,2 \%$ \\
1863 & 122 & 40 & $32,8 \%$ \\
1864 & 139 & 18 & $12,9 \%$ \\
1865 & 37 & 61 & $165 \%$ \\
\hline Brak danych & 9 & $\ldots$ & $\ldots$ \\
\hline Ogółem & 395 & 172 & $43,5 \%$ \\
\hline
\end{tabular}

Pierwszy żołnierz 14. pułku z Luizjany trafił do niewoli federalnej w kwietniu 1862 r. w okolicach Yorktown w Wirginii. Większość kolejnych schwytano podczas wojny właśnie w tym stanie. Wyjątkiem były trzy ofensywy wojsk Południa na Pensylwanię i Maryland. W ich trakcie utracono w ten sposób 99 osób. Ponadto przynajmniej 10 członków regimentu wzięto do niewoli na terytorium Luizjany, gdy przebywali tam na urlopach bądź na akcji rekrutacyjnej. Pojedynczy żołnierze poddali się $w$ innych stanach niż wymienione.

Najwięcej żołnierzy z 14. pułku dostało się do niewoli w bitwie pod Gettysburgiem (1-3 lipca 1863 r.) i w ciągu kilku dni po jej zakończeniu - 79. Przynajmniej $14 \mathrm{z}$ nich trafiło następnie do szpitala De Camp położonego na Davids Island na wybrzeżu Nowego Jorku. Ponadto 24 żołnierzy (w większości dezerterów) dostało się do niewoli, pełniąc służbę patrolową wzdłuż rzek Rappahannock (7-8 listopada 1863 r.) i Rapidan (styczeń - luty 1864 r.). Jednak „czarną" datą dla jednostki, okazał się 12 maja 1864 r., kiedy to pod Spottsylvania Court House zostało pojmanych 74 weteranów regimentu. Wraz z 17 towarzyszami wziętymi do niewoli 5-6 maja 1864 r. pod Wilderness, zostali skierowani do prowizorycznego obozu jenieckiego „na powietrzu” - Belle Plains. Stamtąd przetransportowano ich koleją 19 maja do obozu Point Lookout w stanie Maryland. Gdy wspomniany obóz został zapełniony jeńcami wziętymi w trakcie kampanii generała Ulyssesa Granta, $58 \mathrm{z}$ nich przeniesiono trzema transportami (z dni 25, 26, 28 lipca 1864 r.) do kolejnego obozu - Elmira w stanie Nowy Jork.

${ }^{23}$ Chodzi tu o „600 nieśmiertelnych”, jeńców konfederackich umieszczonych w 1864 r. niedaleko Charleston w Karolinie Południowej w charakterze ,żywych tarcz” - więcej o tym w: Ł. Niewiński, Obozy jenieckie w wojnie secesyjnej 1861-1865, Warszawa-Białystok 2012, s. 122-125. 
Większość jeńców trafiła do obozu Point Lookout (110), przy czym dla wielu z nich okazał się on obozem przejściowym, podobnie zresztą jak Fort McHenry w stanie Maryland (41). Wśród „stałych” obozów jenieckich prym wiodła Elmira (72), Fort Delaware w stanie Delaware (56), Forteca Monroe w Wirginii (41), czy Old Capitol Prison w stolicy USA (37). Jeńcy schwytani w 1865 r. najczęściej trafiali do „nowych” obozów w Newport News w Wirginii (7) lub na Harts Island w Nowym Jorku (8). Innymi miejscami odosobnienia, w których przebywali ,,pensjonariusze” regimentu były: Johnson’s Island w Ohio (2), Fort Columbus w Nowym Jorku (4), Gratiot Street Military Prison w St. Louis, Missouri (3), Camp Morton w Indianie (1) czy Camp Chase w Ohio (2).

Losy jeńców przedstawiały się następująco. Blisko połowa z nich (172) została wymieniona. Niektórych wymieniano nawet dwukrotnie. Jednorazowo wymieniono np. 30 żołnierzy w jednej z pierwszych wymian 5 sierpnia $1862 \mathrm{r}$. w Aikens Landing na rzece James. Dostarczano ich także później do innych miejsc wymiany położonych przy tej rzece, np. City Point (lata 1863-1864) czy Boulwares and Cox Wharf (luty - marzec 1865 r.). Z kolei 4 jeńców z 14. pułku wymieniono 15 listopada 1864 r. w Venus Point niedaleko Savannah w stanie Georgia w ramach wymiany rannych bądź chorych. Dalsze losy aż 78 jeńców (w większości tych wymienionych w 1865 r.) pozostają nieznane.

Unioniści wzięli do niewoli także 72 dezerterów z omawianej jednostki (5,5\% stanu osobowego). Spośród nich co najmniej 19 wstąpiło na służbę Stanów Zjednoczonych (1,5\%), w tym 7 do 3. pułku kawalerii Maryland, a 2 - do marynarki wojennej. $\mathrm{Z}$ dezerterów rekrutowali się w większości ci jeńcy, którzy przed zakończeniem wojny (do maja 1865 r.) podpisali przysięgę wierności rządowi USA i pozostali na Północy - 66. Liczba tak uwolnionych od służby w armii konfederackiej wynosiła w poszczególnych latach: w 1862 r. - 4, w 1863 r. - 20, w 1864 r. - 31, w 1865 r. - 11. Lojalnych względem Konfederacji żołnierzy 14. pułku (58), władze Unii zaczęły zwalniać mniej więcej od połowy maja 1865 r., z tym, że 4 oficerów uwolniono dopiero w drugiej połowie czerwca. Wszyscy byli zobowiązani przed opuszczeniem obozów do podpisania tekstu przysięgi lojalności.

Jak wspominałem wcześniej, w niewoli federalnej zmarło 19 weteranów 14. pułku piechoty z Luizjany. Interesujące, że 2 żołnierzy wziętych do niewoli w kwietniu 1865 r. w szpitalu w Richmond, uciekło z tego szpitala i nigdy nie podpisało przysięgi wierności na rzecz USA.

Ostatnią kategorią żołnierzy występującą w statystykach pułkowych byli ci, przy których nazwiskach brakowało jakichkolwiek informacji (no further record). Z 366 takowych mężczyzn (w tym 78 byłych jeńców), część zmarła lub zdezerterowała, a część została uznana za zaginionych. Wreszcie 27 osób poddało się wraz z armią generała Roberta E. Lee pod Appomattox Court House w dniach 9-10 kwietnia 1865 r. i po zwolnieniu na słowo (parol) zostało od- 
Tabela 11. Lista zabitych, rannych i jeńców z 14. pułku piechoty z Luizjany

\begin{tabular}{|c|c|c|c|c|c|}
\hline Miejsce starcia & Data & $\begin{array}{c}\text { Zabici } \\
\text { (dane oficjalne) }\end{array}$ & Ranni (d. o.) & Jeńcy & Lącznie \\
\hline Williamsburg & 5-6 maja $1862 \mathrm{r}$. & $27(\ldots)$ & $38(\ldots)$ & 53 & 118 \\
\hline Seven Pines & 1 czerwca $1862 \mathrm{r}$. & \multirow{3}{*}{\begin{tabular}{l|l}
28 & $\begin{array}{l}\text { Lacznie } \\
\text { w obu } \\
\text { bitwach } \\
(51)\end{array}$ \\
\cline { 1 - 2 } 23 &
\end{tabular}} & $4(\ldots)$ & 1 & 6 \\
\hline Gaines' Mill & 27 czerwca 1862 r. & & $\begin{array}{c}63 \text { (w obu } \\
\text { bitwach 192) }\end{array}$ & 2 & 93 \\
\hline Frayser's Farm & 30 czerwca $1862 \mathrm{r}$. & & $24+43(?)$ & 4 & 94 \\
\hline Cedar Mountain & 9 sierpnia $1862 \mathrm{r}$. & $1(1)$ & $1(5)$ & 0 & 2 \\
\hline $\begin{array}{l}\text { Kampania 2nd } \\
\text { Manassas }\end{array}$ & $\begin{array}{l}26 \text { sierpnia - } \\
1 \text { września } 1862 \text { r. }\end{array}$ & $12(17)$ & $19(28)$ & 10 & 41 \\
\hline Sharpsburg & 17 września 1862 r. & $7(6)$ & $22+17 ?(47)$ & 10 & 56 \\
\hline Fredericksburg & 13-14 grudnia $1862 \mathrm{r}$. & $\ldots, \ldots$ & $7(5)$ & 0 & 7 \\
\hline Chancellorsville & 1-4 maja $1863 \mathrm{r}$. & $5(4)$ & $26(60)$ & 25 & 56 \\
\hline Gettysburg & 1-3 lipca 1863 r. & $10(9)$ & $36(56)$ & 79 & 125 \\
\hline Payne's Farm & 27 listopada $1863 \mathrm{r}$. & $6(6)$ & $11(15)$ & 2 & 19 \\
\hline Wilderness & 5-6 maja $1864 \mathrm{r}$. & $2(\ldots)$ & $1(\ldots)$ & 17 & 20 \\
\hline $\begin{array}{l}\text { Spottsylvania } \\
\text { Court House }\end{array}$ & 12-20 maja 1864 r. & $\ldots, \ldots$ & $3(\ldots)$ & 74 & 77 \\
\hline $\begin{array}{l}\text { Rajd Early'ego } \\
\text { na Waszyngton }\end{array}$ & $\begin{array}{l}\text { lipiec - sierpień } \\
1864 \text { r. }\end{array}$ & $3(\ldots)$ & $2(\ldots)$ & 10 & 15 \\
\hline $\begin{array}{l}\text { Dolina } \\
\text { Shenandoah }\end{array}$ & $\begin{array}{l}\text { wrzesień - } \\
\text { październik } 1864 \text { r. }\end{array}$ & $4(\ldots)$ & $3(\ldots)$ & 20 & 27 \\
\hline Petersburg & $\begin{array}{l}\text { listopad } 1864 \text { r. - } \\
\text { kwiecień } 1865 \text { r. }\end{array}$ & $\ldots, \ldots$ & $\ldots, \ldots$ & 37 & 37 \\
\hline $\begin{array}{l}\text { Inne potyczki } \\
\text { i wypadki }\end{array}$ & & $2+5$ & $21(\ldots)$ & 51 & 79 \\
\hline $\begin{array}{l}\text { zamieszki w } \\
\text { Grand Junction }\end{array}$ & sierpień 1861 r. & $\ldots(5 \operatorname{lub} 7)$ & (19) & & $\begin{array}{c}24 \text { lub } \\
26\end{array}$ \\
\hline Ogółem & $\begin{array}{l}\text { maj } 1861 \mathrm{r} .- \\
\text { kwiecień } 1865 \text { r. }\end{array}$ & $\begin{array}{l}138(94) \\
+(5-7)\end{array}$ & $\begin{array}{l}338(408) \\
\quad+19\end{array}$ & $\begin{array}{l}395 \\
(\ldots)\end{array}$ & $\begin{array}{c}871 \\
(504)\end{array}$ \\
\hline
\end{tabular}

prawionych do domów. Podobne zwolnienie w rozmaitych miejscach byłej już Konfederacji podpisało pod koniec lub po zakończeniu wojny kolejnych 82 żołnierzy pułku. 
Na podstawie dostępnych źródeł osobowych przedstawiłem dane dotyczące możliwych do zweryfikowania zabitych, rannych i wziętych do niewoli żołnierzy 14. pułku piechoty z Luizjany.

Jednak oficjalne raporty zamieszczone w 128-tomowym Official Records zawierają nieco inne dane, od tych przedstawionych powyżej ${ }^{24}$. Należy przy tym zauważyć, że dane te również nie są precyzyjne. Nie obejmują chociażby bitwy pod Williamsburgiem (maj 1862 r.) oraz ostatnich 6 miesięcy wojny. Ponadto z reguły nie zawierają wykazu jeńców (lub zaginionych), a dla 1864 r. są nieprecyzyjne ze względu na konsolidację resztek pułku z innymi jednostkami z Luizjany. Według dostępnych raportów Official Records liczba zabitych członków regimentu wynosiła 94, a rannych 408 (bez bitwy pod Williamsburgiem i działań zbrojnych z lat 1864-65). Jeńców nie policzono.

Jeszcze inne liczby podawał w swojej pracy Arthur W. Bergeron Jr. Pisał on o: 184 zabitych, 85 - zmarłych z chorób oraz 8, którzy stracili życie w inny sposób. Łącznie pułk stracił bezpowrotnie 277 ludzi, w tym 191 zabitych i zmarłych $\mathrm{z} \operatorname{ran}^{25}$.

Według moich obliczeń łączna liczba zabitych i zmarłych z rozmaitych przyczyn wyniosła łącznie 253 ludzi (bez zabitych w Grand Junction). Zabitych i zmarłych z ran (także jeńców) było 190-192 (łącznie z 5-7 zabitymi w Grand Junction). W tym punkcie obliczenia A. W. Bergerona i moje w zasadzie są tożsame. W wypadku zmarłych z chorób (i utonięcia) Bergeron obliczał ich na 86, podczas gdy mi udało się zweryfikować jedynie $68 \mathrm{z}$ nich. Prawdopodobnie 18 pozostałych zmarłych znajdowało się wśród tych kilkuset, których losów nie udało mi się do końca wyjaśnić.

Ogólna liczba zabitych i zmarłych żołnierzy 14. pułku z Luizjany waha się więc w przedziale 258-279 ludzi. Przy założeniu, że jednostka liczyła, według moich obliczeń 1296 osób, stanowi to $19,5 \%-25,5 \%$ stanu osobowego, a przy liczbie podanej przez A.W. Bergerona - 1026 osób, byłby to rząd wielkości $25,1 \%-27,2 \%$ stanu osobowego.

\section{Zakończenie}

Podsumowując niniejsze rozważania i wyliczenia, należy stwierdzić, że przez okres funkcjonowania 14. pułku piechoty z Luizjany służyło w nim ogółem 1296 żołnierzy. Rekrutacja do jednostki rozpoczęła się w drugiej połowie maja

\footnotetext{
24 The War of the Rebellion: A Compilation of the Official Records of the Union and Confederate Armies, Washington D.C., 1880-1901, ser. 1, t. 11, cz. 2, s. 92, t. 12, cz. 2, s. 180; t. 19, cz. 1, s. 974 ; t. 21 , s. 562 ; t. 25 , cz. 1 , s. 809 ; t. 27 , cz. 2 , s. 506 ; t. 29 , cz. 2 , s. 837.

25 A. W. Bergeron, Jr, op. cit., s. 109.
} 
1861 r., a większość ochotników pochodziła z Nowego Orleanu i zaciągnęła się w pierwszych trzech miesiącach rekrutacji w $1861 \mathrm{r}$. Tylko 556 żołnierzy $(42,9 \%)$ ujawniło swój wiek. Wśród nich kawalerowie stanowili 81,5\% stanu, a mężczyźni żonaci 13,5\%; 5\% nie podało w tym zakresie żadnych danych. Przeciętny wiek żołnierza pułku wynosił w przybliżeniu 26,5 lat. Najwięcej nazwisk rozpoczynało się na literę „M” - 194 (15\%). Mężczyźni z 14. pułku nosili 138 różnych imion. Najpopularniejszym z nich było imię John (198 - przynajmniej 15,3\%). 641 żołnierzy $(49,4 \%)$ podało w momencie rejestracji (lub później podczas pobytu w niewoli Unii) wykonywany zawód. Z 60 zawodów najliczniej reprezentowani byli robotnicy - 301. Miejsce urodzenia podało 666 członków regimentu $(51,3 \%)$. Poza granicami USA urodziło się $376 \mathrm{z}$ nich (29\% całkowitego stanu osobowego jednostki), a na terytorium amerykańskim 290 (22,37\% całkowitego stanu osobowego jednostki). Spośród reprezentantów 13 innych narodowości najwięcej było Irlandczyków - 249. Miejsce zamieszkania ujawniła dokładnie połowa żołnierzy pułku (648). Aż $456 \mathrm{z}$ nich rezydowało w Nowym Orleanie - największym mieście Luizjany. W trakcie konfliktu aż 33 oficerów (ze 106) zrezygnowało ze służby (31\%), a zwolnionych głównie z przyczyn lekarskich zostało 105 ludzi $(8,1 \%$ ogólnego stanu osobowego). Przez okres funkcjonowania jednostki zdezerterowało z niej 280 żołnierzy (21,6\%). Dodatkowo 36 żołnierzy (w tym 7 oficerów) 14. pułku z Luizjany stanęło przed sądami polowymi. Według opracowywanych źródeł 138 żołnierzy pułku zostało zabitych $(10,6 \%)$, kolejnych 115 ludzi zmarło (8,87\%), a rannych zostało przynajmniej 299 weteranów (23\%). Podczas wojny do niewoli Unii trafiło co najmniej 350 żołnierzy 14. pułku (27\%). Jakichkolwiek informacji o dalszych losach brakuje w wypadku aż 366 ludzi.

Reasumując, należy też zaznaczyć, że podane dane statystyczne nie są pełne. Wiąże się to m.in. z fragmentarycznością źródeł. Świadczy o tym chociażby fakt, że autorowi nie udało się rozwikłać losów aż 366 żołnierzy regimentu $(28,2 \%)$. Mniej lub bardziej niepełne informacje okazały się dostępne w zakresie danych, takich jak: wiek, wzrost, kolor oczu, włosów, stan cywilny, miejsce urodzenia czy zamieszkania. Część dokumentów została zniszczona w trakcie działań wojennych, część utracono już po zakończeniu konfliktu. Ponadto nie zawsze dwumiesięczne rejestry osobowe jednostki, do tworzenia których zobowiązywały odpowiednie instrukcje z Departamentu Wojny Konfederacji, były tworzone. Wiele zależało od skrupulatności dowódcy pułku czy poszczególnych oficerów. Warto też dodać, że licznych informacji na temat poszczególnych żołnierzy, dostarczyły badaczowi dokumenty wytworzone przez stronę federalną. Chodzi tutaj głównie o dosyć szczegółowe (niekiedy dublowane) rejestry konfederackich jeńców wojennych. Dane osobowe żołnierzy, którzy dostali się do niewoli Północy, są najlepiej udokumentowane. 


\section{The $14^{\text {th }}$ Louisiana Infantry Regiment in the Civil War (1861-1865)}

The $14^{\text {th }}$ Louisiana Infantry Regiment, called "Polish regiment" has not been properly elaborated in Polish and American historiography. The research on the topic was started by the author of this text in 2007. The aim of this article is to present statistical data concerning this unit, consisting of 1296 soldiers. The recruitment for the unit began in the second half of May 1861, and the majority of the volunteers came from New Orleans. Only 556 soldiers (42.9\%) disclosed their age. The average soldier was 26.5 years old. The name John was the most popular (198 - at least $15.3 \%)$ of 138 names in the regiment. $641(49.4 \%)$ soldiers revealed their occupation. Among 60 occupations, physical workers were the most numerous (301). On the basis of the data provided by 666 soldiers $(51.3 \%)$ concerning their place of birth, it may be concluded that 290 of them were born in America, whereas 376 - abroad. Among the representatives of 13 foreign nations, the Irish were the most numerous -249 . The place of residence was disclosed by a half of the soldiers of the regiment (648). As many as 456 of them resided in New Orleans. During the conflict, 33 officers resigned from the service and 105 people $(8.1 \%)$ were exempted, as, for health reasons, they were unfit for military service. During the functioning of the regiment, at least 280 soldiers (21.6\%) deserted. Additionally, 36 soldiers (among them 7 officers) had trials before martial courts. According to the sources, 138 soldiers of the regiment $(10.6 \%)$ were killed, 115 people $(8.87 \%)$ died and at least 299 veterans $(23 \%)$ were wounded. During the war at least 350 soldiers of the $14^{\text {th }}$ Regiment $(27 \%)$ were in the Union captivity. The fate of 366 people is unknown.

Key words: Civil War, 14th Louisiana Infantry Regiment, Confederate States of America 